\title{
Positive Psychology at Work: Mutual Gains for Individuals and Organizations
}

\section{Psicología Positiva en el Trabajo: Ganancias Mutuas para Individuos y Organizaciones}

\author{
Raquel Rodríguez-Carvajal, Bernardo Moreno-Jiménez, Sara de Rivas-Hermosilla, \\ Abraham Âlvarez-Bejarano and Ana Isabel Sanz Vergel \\ Universidad Autónoma de Madrid
}

\begin{abstract}
Today, workplace is constantly changing. Organizations are confronted with multiple challenges, brought by continuous change. Facing this situation, organizations have opted for two different types of strategies, either the traditional deficit or problem-solving approach or positive-abundance approach which considers that the goal of the organization is to embrace and enable the highest potential of the organization and its employees. A literature review of the latest advances in positive organizational research was conducted in order to shed light onto two main questions: Are mutual gains for the organization and employees possible? And, what does the evidence shows about the development of theory, research and application of positive approaches? Several keywords and descriptors from positive approaches were used. Finally, 154 articles were reviewed. The results point in favor of the mutual gains but also indicate a lack of theoretical development and the need for further research. Other matters are likewise discussed.

Keywords: positive psychology, abundance approach, work, organizations.

Resumen. Actualmente, el lugar de trabajo está cambiando constantemente. Las organizaciones se enfrentan con múltiples retos ocasionados por el cambio continuo. Para enfrentarse a esta situación, las organizaciones han optado por dos tipos diferentes de estrategias, la tradicional aproximación de solución de problemas o déficits y la aproximación positiva o de abundancia que considera que la meta de las organizaciones es conseguir y facilitar el mayor potencial de la organización y de sus empleados. Una revisión de la literatura de los últimos avances en la investigación organizacional positiva ha sido llevada a cabo para clarificar dos importantes cuestiones: ¿son posibles ganancias mutuas para las organizaciones y los individuos? y ¿qué muestra la evidencia sobre el desarrollo de teoría, investigación y aplicación de las aproximaciones positivas? Se utilizaron varias palabras clave y descriptores y finalmente se revisaron 154 artículos. Los resultados indican ganancias mutuas pero también señalan la falta de desarrollo teórico y la necesidad de más investigación. También se revisan otras cuestiones.

Palabras clave: psicología positiva, trabajo, organizaciones, ganancias.
\end{abstract}

Today's workplace is constantly changing. Organizations are confronted with multiple challenges, brought by continuous change: globalization, new technologies, growing cultural differences, changes in employees' and customers' needs and values, and a constant demand for efficacy and efficiency. Organizations are required to adapt in order to remain competitive, especially in a particularly difficult marketplace following the recent global financial crisis. It is well known that this situation is also challenging the well-being and health of the working population, with repercussions on economy itself. The Government, insurance companies, and organizations suffer from a significant drain on resources due to work-related illhealth problems, working days lost, sick leaves,

Correspondence on this article should be sent to the first author at Facultad de Psicología, Universidad Autónoma de Madrid, c/ Iván Paulov, 6, 28049, Madrid, España. E-mail: raquel.rodriguez@uam.es turnover and the subsequent costs of searching and training new employees. For instance, according to the European Agency for Safety and Health at Work (2009) it is estimated that an average of 1,250 million working days are being lost each year due to workrelated ill- health problems. Studies suggest that between $50 \%$ and $60 \%$ of all lost working days have some link with work-related stress.

Facing this situation, organizations have opted for two different types of strategies, either a deficit (problem-solving) approach or an abundance approach. According to Linley et. al (2010) a deficit or problemsolving approach is characterized by the identification of the key problems and challenges that faces the organization; the generation of alternative solutions to these problems trough the identification of their root causes; the evaluation and choice of the most optimal solution; and finally the implementation of the chosen solution until the problem is solved. The role of the manager is dealing with the deficit as problem-solver. 
The focus is, by definition, on the negative, in the form of the problems to be solved and the deficits to be filled (Linley, Harrington \& Garcea, 2010). In the framework of this approach, employees' health and well-being are considered in negative terms, a fact that implies that concepts such as job burnout, psychological distress, and dissatisfaction are considered as problems to solve to reduce costs (Wright \& Quick, 2009a; Wright \& Quick, 2009b).

On the other hand, the abundance approach considers that the goal of the organization is to embrace and enable the highest potential of both, the organization and its people. Employees' health and well-being are viewed as ends in their own right. Health is defined in terms of both the absence of dysfunctional behavior and the presence of human growth and betterment (Wright \& Quick, 2009a; Wright \& Quick, 2009b). Some of the antecedents of abundance are positive organizational culture and climate, positive leadership practices and positive personal resources (Ulrich, 2010). As stated by Linley, Harrington and Garcea (2010) creating and maintaining an abundance organization involves: first, identifying the moments in which the organization and its people perform at their best (in a broad sense, including their own personal growth); second, identifying and understanding what makes possible these optimal performances and which optimal performance enablers can be continued and replicated in the future; and finally, designing interventions that aim to an ideal, desired future characterized by outstanding performance.

As an antecedent of this view, early in 1946, World Health Organization Constitution defined health as "a state of complete physical, mental and social wellbeing and not merely the absence of disease or infirmity". Nevertheless, it may be said that a systematic research of positive aspects did not begin until Seligman and Csikszentmihalyi's (2000) call for a "positive psychology". The same applies for organizational psychology. It was from that moment when other positive psychological approaches such as Applied Positive Psychology (APP), and Positive Organization Behavior (POB), as well as Positive Organizational Scholarship (POS), arise from the stand of positive psychology, to apply it to the workplace (i.e., Bakker, \& Schaufeli, 2008; Luthans \& Youssef, 2007; Wright \& Quick, 2009a).

Applied positive psychology "is the application of positive psychology research to the facilitation of optimal functioning" (Linley \& Joseph, 2004: 4). It includes not only the organizational life, but it is concerned about the applications of positive psychology in a broader sense, being work one of the contexts of application (Linley, Harrington \& Garcea, 2010).

POB is define by Luthans as "the study and application of positively oriented human resource strengths and psychological capacities that can be measured, developed, and effectively managed for performance improvement in today's workplace" (Luthans, 2002, p. 59). In addition, there are three inclusion criteria for POB: being based on theory, research and valid measurement; being state-like and consequently open to development, and having performance impact (Luthans \& Avolio, 2009a). Similar to POB, but differing in several aspects, POS is defined as being “... concerned primarily with the study of especially positive outcomes, processes, and attributes of organizations and their members. POS does not represent a single theory, but it focuses on dynamics that are typically described by words such as excellence, thriving, flourishing, abundance, resilience, or virtuousness. POS represents an expanded perspective that includes instrumental concerns but puts an increased emphasis on ideas of "goodness" and positive human potential." (Cameron et.al, 2003, p. 4). Thus, POB is primarily concerned with the temporary or state-like characteristics that influence employees' performance whereas POS deal with more stable or trait-like qualities (i.e., Luthans \& Avolio, 2009a; Wright \& Quick, 2009b) and the positive aspects of the organizational context that influence employee's thriving (i.e., Bakker \& Schaufeli, 2008).

These positive or abundance approaches does not proclaim to be entirely new discoveries but rather emphasize the need for more focused theory building, research and effective application of the positive aspects (i.e., Luthans \& Youssef, 2007). Other developments such as appreciative inquiry, community psychology, and prosocial behavior have moved in a positive direction too, although sometimes (as the case of appreciative inquiry) success and popularity could have preceded them (i.e., Cameron et. Al. 2003), finally they might not get such attention and/or theory development as POB and POS in organizational psychology.

Therefore, there is an abundance approach in the one hand, which takes into account the organization and its people, and thus search for mutual gains; and a deficit approach in the other hand, that focuses on organizational problems to solve, sometimes also considering employees' well-being, sometimes not. All of this taking place in the scene of today's increasingly complex and rapidly changing environment, that is, a juncture demanding more and more resources from organizations as well as their employees, besides people's increasing concern about their own well-being. So, in order for organizations to remain competitive, they should attend on the one hand to their best results and on the other to promote the well-being of employees, which seems similar to adopting an abundance approach. In that case, a question arises: are mutual gains possible? What does the evidence collected through the last five years suggest? And what does this evidence show about the development of theory building, research and application of abundance approaches? 
To answer these questions a literature review of the latest advances in positive organizational research was conducted.

\section{Method}

Computer and manual searches were conducted to find articles regarding positive approaches in organizations and their positive outcomes such as satisfaction, happiness, well-being, engagement, flow, positive emotions, flourish and personal growth. We focused in these positive employee outcomes as this was our starting point. Besides, we looked for well known organizational positive approaches and some positive leadership styles. We were searching for publications from the last five years (2005-2010). Various combinations of descriptors (for the most numerous) and keywords were entered into the PsycINFO database, e.g.: positive psychology (65 articles), positive organizational behavior (34 articles), positive organizational scholarship (28 articles), job satisfaction (2456 articles), happiness (46 articles), well-being (549 articles), engagement (168 articles), authentic leadership (73 articles), deviant leadership (1 articles), transformational leadership (282 articles) and servant leadership (130), emotion (821), flow(6), flourish (5) and personal growth (21); all combined with either job or work or organization as additional descriptors to restrict the studies to work-settings. From this primary search we focus on peer reviewed publications and books. In order to obtain additional older key articles meeting our initial criteria, a retrospective search through references of retrieved impact journals as well as the most cited ones was conducted.

After reading all abstracts and titles, the initial literature search resulted in 154 articles that appeared relevant for our purpose.

\section{Results}

The results of the review that was carried out will be organized, in the following lines, in two main parts. In the first place we will focus on the individual level and we will describe the main factors related to important employees' positive psychological outcomes. Afterwards, in order to contrast whether or not an abundance approach is also beneficial for organizations, we will synthesize the evidence that has been collected so far relating organizational outcomes with positive practices and constructs.

On the other hand, as a general summary about the methodology used in the studies reviewed, almost all the studies show correlational or descriptive methods. Besides, within the total of 154 articles reviewed, only 21 count with longitudinal designs. In the following lines, we describe the variables related directly or indi- rectly to different forms of individual psychological gains.

\section{How to increase job satisfaction and well-being}

\section{Organizational culture, organizational policies, and job characteristics}

At the broadest level, research has investigated several aspects of organizational culture and juncture that might act as antecedents of positive individual outcomes. In general terms, it has been suggested that organizational culture and climate dimensions are differentially and significantly related with job satisfaction (i.e., Berson, Oreg \& Dvir, 2008; Giri \& Kumar, 2007; Liao \& Rupp, 2005; Schulte, Ostroff \& Kinicki, 2006). In a more particular level, different organizational practices and strategies have been investigated. Luna-Arocas and Camps (2008), for example, analyzed the effects of salary and job enrichment strategies on job satisfaction and found a positive association between them. Other studies have suggested that organizational support (both formal and informal) and supportive climate are predictive of general satisfaction (Luthans, Norman, Avolio \& Avey, 2008), employee well-being (Lapierre \& Allen, 2006; Thompson \& Prottas, 2006) and general health indicators (Jain \& Sinha 2005). This relationship was found to be mediated by employees' attitudes such as affective commitment (Panaccio \& Vandenberghe 2009) and perceived control (Thompson \& Prottas, 2006). In this sense, it was suggested from a field experiment study that concrete practices such as facilitation mentoring programs produced significant positive effects on new employee's work satisfaction (Egan \& Song, 2008). Others positive organizational policies as opportunities for learning and personal development were related with affective well-being, with perceptions of work-family conciliation as a moderator of this relationship (Rego \& Pina e Cunha, 2009).

Regarding work-family conciliation, there are a variety of family-friendly organizational practices, programs and policies that some organizations have implemented in order to help their employees balance their family and work demands solving or avoiding work-family conflicts. Examples of these practices are flexible scheduling, compressed work week, telecommuting, on-site childcare, part-time schedules, and job sharing (Baltes, Clark \& Chakrabarti, 2010). Many of these organizational family- friendly policies might be listed under other labels such as organizational support, supportive climate and job resources. While research on work-family conflict shows the problem, studies on work-family facilitation show the effects produced by these friendly-family policies. In this regard, work-family conflict has repeatedly been found in negative correlation with job satisfaction (i.e., 
Bagger \& Gutek, 2008; Boyar \& Mosley, 2007; Carr, Boyar \& Gregory, 2008; Ford, Heinen \& Langkamer, 2007; Grandey, Cordeiro \& Crouter, 2005; Lapierre, et al., 2008; Mesmer-Magnus \& Viswesvaran, 2005), life satisfaction (i.e., Moreno-Jiménez et al., 2009; Cunningham \& de la Rosa, 2008; Mesmer-Magnus \& Viswesvaran, 2005) with recovery strategies as a moderator variable (Moreno-Jiménez et al., 2009) and, family satisfaction (Ford, Heinen \& Langkamer, 2007). In this last relationship, family identity salience (i.e., Bagger \& Gutek, 2008; Carr, Boyar \& Gregory, 2008) and gender (i.e., Bagger \& Gutek, 2008; Grandey, Cordeiro \& Crouter, 2005; Mesmer-Magnus \& Viswesvaran, 2005) might be mediator and moderator variables respectively. On the other hand, workfamily facilitation (job resources in general as well as concrete family-friendly policies and informal support) predicts positively job satisfaction (Boyar \& Mosley, 2007; Illies, Wilson \& Wagner, 2009; Mauno, Kinnunen \& Ruokolainen, 2006), daily marital satisfaction (Hill, 2005; Illies, Wilson \& Wagner, 2009), positive affect at home (Illies, Wilson \& Wagner, 2009), life satisfaction and well-being (Thompson \& Prottas, 2006) in workers. Besides, recovery strategies and conditions have been found to be predictors of work family facilitation as well (i.e., Sanz-Vergel, Demerouti, Moreno-Jiménez \& Mayo, 2010). It may be important to note that some studies found more relevant the informal factors, such as having supportive colleagues and bosses and the perception on the part of the employees that there will not be negative job or career consequences when using family policies, than the formal availability of family-friendly benefits alone (i.e.: Thompson \& Prottas, 2006).

In other matters, concerning mayor transitions, such as mergers, acquisitions, downsizings, and restructurings, Marks (2006) has referred that "studies consistently show that, in the aftermath of transitions involving layoffs; survivors' attitudes in areas including job satisfaction, job involvement, organizational commitment, and intention to remain with the organization become more negative". Research directed onto the clarification of factors mediating the above mentioned relationship has suggested that employees' attitudes towards change such as positive and negative feelings towards the specific change, employees' intention to act against the change, and employees' evaluation of the worth and potential benefit of the change (Oreg, 2006) and other person-related variables, such as employee engagement (Marks, 2006) and coping style (problem focus coping versus avoidance coping) (Amiot, Terry, Jimmieson \& Callan, 2006) should be taken into consideration.

Finally, researchers have also analyzed the effect of job characteristics on employees' well-being. There is evidence suggesting that job characteristics do not determine, per se, neither the levels of reported job satisfaction, well-being nor stress. Instead, job character- istics typically labeled as job stressors (workload, emotional demands, etc.) might be perceived as challenges or hindrances (Wiese \& Freund, 2005; Podsakoff, LePine \& LePine, 2007), or job resources might moderate the above mentioned relationship and even in some cases reverse its negativity (Zickar, Balzer, Aziz \& Wryobeck, 2008; Bakker, van Veldhoven \& Xanthopoulou, 2010).

Nevertheless, although it has been appointed to its relative effects, the effect of job characteristics on job satisfaction and positive affect has also been considered. Evidence suggests that both, perceptions of job control (Petrides \& Furnham, 2006), job autonomy (Thompson \& Prottas, 2006) break activities implementation (Trougakos, Beal, Green \& Weiss, 2008) and recovery time (i.e, Sanz-Vergel, Demerouti, Moreno-Jiménez \& Mayo, 2010; Sonnentag \& Zijlstra, 2006) might have beneficial effects on individuals' affect and well-being.

\section{Leadership}

On one hand, in the literature it is found that satisfaction with supervisors has a positive impact on job satisfaction, explaining in some cases up to $80.7 \%$ of the variance (i.e., Mardanov, Heischmidt \& Henson, 2008). On the other hand, as stated in the review conducted by Avolio and colleagues (2009), nowadays, the field of leadership focuses on different aspects such as followers, peers, supervisors, work context, and culture as well as on the leader per se. That is because leadership is no longer just defined by individual characteristics or differences, but rather it is inserted in more complex models which take into account dyadic, shared and social relational dynamics (Avolio, Walumbwa \& Weber, 2009).

Concerning positive leadership, several approaches can be found in the literature that seems to adjust to this label to some extent. Some examples are: transformational leadership (sometimes called inspirational leadership), positively deviant leadership and authentic leadership. Nevertheless, in spite of being in some way, abundance oriented, and considering followers in their models, none of these types put employee well-being under its concerns, at least not directly. The exception is made with a different one: servant leadership. A servant leader (SL) focuses on the development, growth and well-being of the individual; it's a people-centered theory of leadership (van Dierendonck \& Nuijten, in press). A generally accepted definition of SL is not established (Andersen, 2009), however it may be said that typical attributes of a servant leader include empowerment; accountability; standing back, giving support and credits; humility; authenticity; courage, taking risks and trying out new approaches to old problems; interpersonal acceptance, being able to forgive when con- 
fronted with offenses, arguments, and mistakes; and stewardship, the willingness to take responsibility for the larger institution and go for service instead of control and self-interest (van Dierendonck \& Nuitjen, in press). On the other hand, limited research has been conducted in regard (Avolio, Walumbwa \& Weber, 2009; Washington, Sutton \& Field, 2006) although SL is not a new concept (Greenleaf, 1977). In their review, Avolio and colleagues (2009) introduced that the limited empirical research has shown that SL is positively related to follower satisfaction, their job satisfaction, intrinsic work satisfaction, caring for the safety of others, and also organizational commitment. In addition, a recent study with the eight core servant leadership dimensions in Dutch and UK samples showed positive relationships with vitality, and engagement (van Dierendonck \& Nuijten, in press). Besides, the relationship between SL and job satisfaction was found to be mediated by organizational justice and need satisfaction (Mayer, Bardes \& Piccolo, 2008). Also, the relation between employees' perceptions of SL and organizational trust has been examined (Joseph \& Winston, 2005) and a positive relationship was reported with both trust in the leader and trust in one's organization. As part of others studies, the relationship between SL and the leader's values of empathy, integrity, competence, and agreeableness was tested too. The authors informed that followers' ratings of leaders' SL were positively related to followers' ratings of leaders' values of empathy, integrity, and competence and positively related to the leaders' ratings of their own agreeableness (Washington, et. al, 2006).

On the other hand, transformational leadership (TL) brings some positive characteristics that might be included as part of the abundance approach (Avolio, Walumbwa \& Weber, 2009), and as TL is, perhaps, the most developed and consequently probably the most studied of these somehow positive leadership styles, there are several studies linking it to positive individual outcomes. A TL is supposed to employ a visionary and creative style of leadership that inspires employees to make independent decisions and develop in their work (Nielsen \& Munir, 2009). TL has been positively associated with followers: job satisfaction (Liu, Shiu \& Shi, 2010; Walumbwa et.al, 2005), empowerment (Avey, Hughes, Norman \& Luthans, 2008; Gumusluoglu \& Ilsev, 2009; Meyerson \& Kline, 2008), psychological well-being (Nielsen, Randall, Yarker \& Brenner, 2008), positive affective well-being (Arnold et. al., 2007; Nielsen \& Munir, 2009), positive emotions (Bono, Foldes, Vinson \& Muros, 2007) and highly social support perceptions (Lyons \& Schneider, 2009). The relations with psychological well-being and positive affective well-being were apparently mediated by follower meaningfulness (Arnold et. al., 2007; Nielsen, Randall, Yarker \& Brenner, 2008) and self-efficacy (Nielsen \& Munir, 2009).
Similar to TL, in that it shares characteristics that may pertain to abundance approach, is authentic leadership (AL). The idea of authentic leadership, as reported by their authors (i.e., Avolio, Griffith, Wernsing \& Walumbwa, 2010), "came as a result of writings on transformational leadership where it was suggested that there were pseudo versus authentic transformational leaders". From this statement, and within positive organizational behavior approach, AL has been defined as "being self-aware, genuine, optimistic, balanced in terms of decisionmaking, and transparent in enacting leadership that energizes people, builds trust, and reinforces and develops the leaders' and followers' strengths and self-awareness" (Avolio, Griffith, Wernsing \& Walumbwa, 2010). In this case, results show that employee perception of AL positively predicts employee satisfaction and work happiness (Jensen \& Luthans, 2006).

Finally, we would like to add a comment regarding positively deviant leadership (PDL). The concept of PDL emerges from positive organizational scholarship when diving into the field of strategic management. A positively deviant leader focuses on enable positive dynamics and foster extraordinary performance through his/her strategy and behavior (Wooten $\&$ Cameron, 2010). As we have already said, the PDL doesn't focus on employee wellbeing directly; instead he/she focuses on innovation, entrepreneur, vision, constant change, which can derive or not into employee well-being. As the concept of PDL stems from the idea of a deviance continuum (from negative to positive) (Wooten \& Cameron, 2010) all type of leaders should be allocated in that continuum, thus PDL refers to those who behave close to the positive pole.

\section{Personal resources}

\section{Positive psychological capital}

Positive psychological capital is a global construct that comprise four different personal resources: hope, resilience, optimism and efficacy. Positive psychological capital has focused in these four psychological resources although they do not intend to represent an exhaustive taxonomy (Youssef \& Luthans, 2010). This construct was directly related to job satisfaction (Larson \& Luthans, 2006; Luthans, Avolio, Avey \& Norman, 2007; Luthans, Norman, Avolio \& Avey, 2008) as well as psychological well-being (Avey, Luthans, Smith \& Palmer, 2010) and positive emotions (Avey, Wernsing \& Luthans, 2008). Besides, it has been suggested that psychological capital interacts with mindfulness in predicting positive emotions (Avey, Hughes, Norman, \& Luthans, 2008). 


\section{Psychological Flexibility}

Psychological flexibility is defined as being in contact with the present moment as a conscious human being, and, based on what that situation affords, acting in accordance with one's chosen values (i.e., Hayes, Strosahl \& Wilson, 1999; Bond, Hayes \& BarnesHolmes, 2006). There are six processes involved: acceptance, cognitive defusion, being in the present moment, self as context, values and committed action. Each of these processes are supposed to be not just a strategy for preventing and alleviating psychopathology but a positive psychological skill themselves (Bond et al., 2010).

Although psychological flexibility is mainly a theory of psychological health (recently developed within the acceptance and commitment therapy (ACT) in a contextual approach), the implications of it, as argued by Bond (2010) may help people to be sensitive to, and contact, contingencies of reinforcement that bear on chosen values (for example doing well at work, even if it is just to get paid), thus making clear its usefulness to the work setting (Bond, Flaxman, van Veldhoven \& Biron, 2010).

There is strong evidence of the positive relation of psychological flexibility and health as shown in a recent meta-analysis (Hayes et al., 2006) and evidence providing support for the hypothesis that psychological flexibility is associated with mental health related outcomes in work settings is gradually accumulating (Bond, Faxman, van Veldhoven \& Biron, 2010). In that sense most of the research on psychological flexibility and health is focus on preventing the negative outcomes, thus relating it with positive outcomes such as job satisfaction and general well being.

As stated in a chapter review of Bond et al. (2010), they tested the utility of promoting psychological flexibility, through an ACT stress management intervention for the first time. They tested it with a randomized controlled experiment in employees and found positive results for ACT and psychological flexibility when reducing mental ill-health at work. Other studies have showed that these interventions helped professional caregivers (social workers, police, physicians) in the face of danger and human suffering, reducing the incidence of secondary or vicarious trauma (Berceli \& Napoli, 2006). Finally, it has been also found to be effective in preventing burnout in palliative care workers (Ruiz, Rios \& Martín, 2008).

As we have seen, psychological flexibility has been studied mostly reducing negative outcomes, however it is itself a positive personal resource. In this line, Bond (2004) recommends stress management approaches that combine interventions targeted at the work environment with interventions targeted at the person, not only to reduce negative outcomes but al-so as a preventive strategy in line with a positive approach.

\section{Self-regulation processes}

As it is stated in a recent review (Lord et al., 2010), when one want to success in nowadays work organizations, self-regulation is important. There is an increasing emphasis on personal initiative and empowerment, thus, taking control of one's own goal-directed activities is of great relevance. Besides, self-regulate also yield benefits such as enhance individual growth and development, greater well-being and self-realization (Lord et al., 2010).

In this regard, there is evidence supporting that problem-focused, cognitive restructuring coping styles, and reappraisal strategies have beneficial effects on positive individual outcomes such as job satisfaction (Amiot, Terry, Jimmieson \& Callan, 2006; Ayres \& Malouff, 2007), greater positive affect, higher life satisfaction, and well-being (Ayres \& Malouff, 2007; Welbourne, Eggerth, Hartley, Andrew \& Sanchez, 2007; Rodríguez-Carvajal, 2007). Contrary, self-regulation processes such as suppressing and faking emotions seem to generate the opposite effect (Bono, Foldes, Vinson \& Muros, 2007; Glas $\varnothing$ \& Einarsen, 2008; Rodríguez-Carvajal, 2007; Seery \& Corrigall, 2009; Yanchus, Eby, Lance \& Drollinger, 2010). Concerning this point, some authors have reported the partial mediation of emotional dissonance in the process (Van Dijk \& Brown, 2006; Zapf, D. \& Holz, M., 2006), while others in turn have stressed the moderating effects of gender and perceived autonomy at work (Johnson \& Spector, 2007).

In another study, affective well-being, work satisfaction and subjective developmental success were positively associated with self-reported progress in the pursuit of personal goals within the work domain (Wiese \& Freund, 2005). However, in this study, goal progress itself did not predict an increase in affective well-being and work satisfaction and this relation was fully mediated by goal difficulty; in this sense, only when goals were perceived as difficult to achieve, individuals reported a change in positive and negative affect, job satisfaction and subjective developmental success. A more recent study (Pomaki, Karoly \& Maes, 2009) pointed out in a similar direction, their findings suggested that work goal progress was not directly associated with well-being, instead they found that this relation was moderated by goal cognition. The differences between the starting point marked the relation in the sense that individuals who started off with unfavorable goal cognitions and who managed to achieve goal progress reported an increase in well-being, compared with those who had at first favorable goal cognitions and later similar rates of progress.

\section{Positive attributional style}

Workers' attributional style has also been taken into 
account. Research on this topic has suggested that positive occupational attributional style is positively related with job satisfaction (Welbourne, Eggerth, Hartley, Andrew \& Sanchez, 2007) and it can be improved through cognitive-behavioral therapy (Proudfoot, Corr, Guest \& Dunn, 2009). In a more specific analysis, Wellbourne et al. (2007) found that the above mentioned relationship was mediated by the coping style used by workers. In that case, a positive attributional style to their occupation was associated with greater use of problem solving/cognitive restructuring coping styles and less use of avoidance coping styles to deal with the stress in the workplace and consequently reporting higher levels of job satisfaction.

\section{Emotional Intelligence}

Another personal factor that has attracted researchers' attention is emotional intelligence (EI). EI is a controversial concept. According to Jain, and Sinha (2005), some authors have found the concept of little relevance. However, there are some others who advocated the concept. In turn, there are different conceptions of EI, the ability model, proposed by Mayer and Salovey and the mixed models proposed by Goleman and also by Bar On (Jain \& Shina, 2005). The first one asserts that EI is the ability to perceive and express emotion as well as the assimilation of emotions in thought, understanding, and reasoning; and the regulation of emotion in oneself and others. The second one is defined by Goleman on the basis of traits that include self-control, zeal, persistence, and the ability to motivate oneself. And by Bar $\mathrm{On}$ as an array of noncognitive capabilities, competencies, and skills that influence one's ability to succeed in coping with environmental demands and pressures (Jain \& Shina, 2005).

In general, EI studies regarding workplace, suggest that EI is positively related with job satisfaction and other well-being related indicators (i.e., Jain \& Shina, 2005; Sy, Tram \& O'Hara, 2006; Kafetsios \& Zampetakis, 2008). Positive and negative affect may mediate the abovementioned relationship; particularly, in the case of males, where a full mediation effect may exist, according to Kafetsios and Zampetakis (2008). On the contrary, managers' EI may enhance employee's job satisfaction when subordinates' EI is low, (Sy, Tram \& O’Hara, 2006).

\section{Core-self evaluations}

At the most particular level, researchers have investigated the effect of several personal resources on job satisfaction, well-being and positive affect. Among the different personality variables, research has recently focused on the construct of core-self evaluation (CSE).
CSE was a concept introduced by Judge et al. (1997) as an integrating principle for understanding the personal trait basis of job satisfaction (Bono \& Judge, 2003). CSE includes self-esteem, locus of control and emotional stability, as they are supposed to be so closely related conceptually and empirically that would compound a higher level dispositional core self-evaluation factor (Judge et al., 2002). CSE has provided some evidence for its direct and indirect (trough goal self-concordance) influence on job satisfaction (Best, Stapleton \& Downey, 2005; Piccolo, Judge, Takahashi, Watanabe \& Locke, 2005; Judge, Heller \& Klinger, 2008). Piccolo, Judge et al. (2005) examined the potential of different dispositional constructs in predicting job satisfaction and reported that CSE measure displayed, in general terms, higher correlations with job satisfaction than positive and negative affectivity. In the same line, Judge et al. (2008) compared CSE, Big Five, and trait affectivity in relation to job satisfaction, and reported that, despite their significant influence on the outcome referred, only core self-evaluations correlated significantly with it when all typologies were examined concurrently. Moreover, initial support has been provided for the generalizability of the CSE construct and predictive properties in nonWestern cultures (Piccolo, Judge, Takahashi, Watanabe \& Locke, 2005).

\section{Getting Engagement}

Work engagement is a slippery concept because sometimes behind the label there are very different interpretations (Schaufeli \& Bakker, 2010; Stairs \& Galpin, 2010). As Schaufeli and Bakker (2010) explain in their analysis of the several definitions of engagement in business context, consultants sometimes use that word to refer to traditional concepts such as affective commitment, continuance commitment, extra-role behavior and sometimes even job characteristics, thus mixing work conditions and behavior with subjective experiences (Bakker \& Leiter, 2010). A different approach, which is reviewed here, conceives employee engagement independently from job resources and positive organizational outcomes as a positive, fulfilling, affective-motivational state of work-related well-being characterized by vigor, dedication and absorption (i.e., Bakker \& Schaufeli, 2008; Bakker, Schaufeli, Leiter \& Taris, 2008; , Bakker \& Leiter, 2010). This definition focuses on employees'experience of work activity, and not the predictors or outcomes of these experiences. Thus, in order to gain insight onto the circumstances under which employees feel engaged, we must figure out what the predictors of the engagement experience are. In this sense, job resources (i.e., social support from colleagues and supervisors, autonomy, performance feedback, supervisory coaching, etc.) have consistently been positively associated with work engagement (i.e., 
Bakker \& Demerouti, 2007, 2008; de Lange, de Witte \& Notelaers, 2008; Schaufeli \& Salanova, 2007; Schaufeli, Bakker \& van Rhenen, 2009) resulting the most important predictors when studied within the comprehensive model of Job Demand-Resources (JD-R) (Hakanen, Schaufeli \& Ahola, 2008). Job resources refer to "those physical, social, or organizational aspects of the job that may: (a) reduce job demands and the associated physiological and psychological costs; $(b)$ be functional in achieving work goals; or (c) stimulate personal growth, learning, and development" (Bakker \& Leiter, 2010). Along with job resources, personal resources positively impact in work engagement (i.e, Avey, Wernsing \& Luthans, 2008; Bakker \& Demerouti, 2008; Garrosa, Moreno-Jiménez, Rodríguez-Muñoz \& RodríguezCarvajal, in press). Moreover, the whole model proposes this previous relationship to be moderated by job demands, meaning for instance, that in conditions of high job demands, job resources result more beneficial in maintaining work engagement (i.e., Hakanen, Bakker \& Demerouti, 2005; Hakanen, Demerouti \& Xanthopoulou, 2007). Finally in the model, as it will be seeing later, work engagement seems to be positive related to performance.

\section{Experiencing Flow}

Flow has been described as "a particular kind of experience that is so engrossing that it becomes autotelic, that is, worth doing for its own sake even though it may have no consequence outside itself" (Csikszentmihalyi, 1999, p. 824). In that state the person feels challenged, draws on his or her specific skills, enjoys the moment, thereby stretches his or her capabilities, and loose the perception of time.

As stated in different studies (i.e.: Bakker, 2008; Demerouti, 2006; Rodríguez-Sánchez, Schaufeli, Salanova \& Cifre, 2008) three core elements of flow can be identified: absorption, which refers to the absolute concentration and involvement in the activity; enjoyment, which refers to the experience of enjoying the activities; and intrinsic motivation, which refers to the need to perform a certain activity because of the fascination of the activity. On the other hand, Csikszentmihalyi (1999) established the following key elements to comprehend the essence of experiencing flow: having challenge-skills balance, actions-awareness merging, clear goals, unambiguous feedback, concentration on task at hand, sense of control, loss of self-consciousness, transformation of time, and an autotelic experience.

Flow theory points out that work settings, because of their characteristics, usually provide opportunities for experiencing flow, and in turn it claims that work should be organized to facilitate the experience of flow (i.e.: Csikszentmihalyi, 1999). However, there is very little empirical research in respect to flow experience at work. And consequently there are only a few studies that shed light onto it.

Nielsen and Cleal (2010) studied in managers which kind of tasks may best predict transient flow states at work. They found that planning, problem solving, and evaluation were all activities significantly predicting flow. In another study of Salanova et al. (2006) is showed that social support, support for innovative practices at work, having clear rules and norms at work, and having clear goals were related to flow. Besides, it was found that as well as personal and organizational resources facilitate flow at work, flow itself influence on both personal and organizational resources (Salanova, Bakker \& Llorens, 2006). Other studies showed that motivating job characteristics such as skill variety, autonomy, job feedback, task identity, and task significance were predictive of flow (Demerouti, 2006; Kuo \& Ho, 2010). In addition, meditation experience has also been found to be positively related to flow experience (Kuo \& Ho, 2010).

Finally, besides being flow perceived to be worth doing in itself, additional benefits for organizations and employees have also been identified, for example: job satisfaction, enthusiasm, and contentment (Nielsen \& Cleal, 2010).

\section{Organizational gains from abundance approach}

In the next section we proceed to describe the results found for the positive variables related in one way or another with different organizational gains.

\section{Enhancement of performance-related organizational outcomes}

Performance is usually divided into in-role performance (similar to task performance), defined as fulfillment of tasks that are required by the formal job description, -sometimes authors refer to this type just as performance-, and extra-role performance (related to contextual behavior and organizational citizenship behavior-OCB-), defined as behavior that is beneficial to the organization and goes beyond formal job requirements (e.g., helping colleagues at work, working extra hours, making suggestions for improvement, etc.) (i.e.: Riketta, 2008). In the following lines, we present a review of the studied variables related to job performance and extra-role performance, when these last were functioning as dependent variables.

\section{Positive organizational culture, climate, and policies}

At the broadest level, positive approaches have investigated the beneficial effects of positive organizational cultures and climates on performance and extra- 
role performance. A positive relationship might exist between positive emotional climate practices and company performance and growth (i.e., Ozcelik, Langton \& Aldrich, 2008; Ramlall, 2008). Some studies suggests that enhancing employees' empowerment (i.e., Butts, Vandenberg, DeJoy, Schaffer \& Wilson, 2009), strengthening social ties among workers (i.e., Bowler \& Brass, 2006) and construing positive social networks at work (Xenikou \& Simosi, 2006) might result in increasing job performance and extra-role performance, pointing out, in the case of empowerment, the moderator effects of perceived organizational support. Other studies, positively relate perceive organizational support with higher levels of task and contextual performance behaviors throughout affective commitment. In this relationship, work-life benefits provided by the organization were also positively related to organizational support, thus indirectly to performance (Muse, Harris, Giles \& Field, 2008). In addition, a supportive climate also predicts better performance throughout psychological capital (Luthans, Norman, Avolio \& Avey, 2008), whereas colleague support has an indirect effect on in-role performance through work engagement (Xanthopoulou, Baker, Heuven, Demerouti \& Schaufeli, 2008).

\section{Leadership}

As discussed before, servant leaders focus primarily on employees needs instead of organizational objectives, however, some authors argue that it is possible to expect positive organizational outcomes from SL. For instance, Hamilton (2005) proposed several outcomes to be derived from servant-leadered organizations, including mission and value focus, creativity and innovation, responsiveness and flexibility, commitment to both internal and external service, respect for employees; employee loyalty and celebration of diversity. According to Andersen (2008), empirical evidence for these assumptions was not available till that date. Nevertheless, and as far as our review has led, we have retrieved three studies examining some of these (and others) relationships. On one hand, Liden et al., (2008) tested the relation between SL and organizational citizenship behavior, in-role performance and organizational commitment. They analyzed this relation controlling for transformational leadership and leadermember exchange, and found positive correlations for all of them. On the other hand, Neubert et al., (2008) found that SL positively predicted creative and helping behavior, but this relation was mediated by promotion focus (from regulatory focus theory, see i.e., Higgins, 1997). Finally, Van Dierendonck and Nuijten (in press) also found positive relationships with in-role performance and extra-role behaviors as civic-virtue, altruism and taking charge both in Dutch and UK samples.

Regarding transformational leadership, there are more evidence showing a positive relation with performance. TL is positive related to employee creativity (Gong, Huang \& Farh, 2009; Gumusluoglu \& Ilsev, 2009) and organization innovation (Gumusluoglu \& Ilsev, 2009; Jung, Wu \& Chow, 2008). Employee creativity is in turn positively related to employee sales and supervisor-rated employee job performance (Gong, Huang \& Farh, 2009). In addition, followers' perception of TL and TL is positive related to employee in-role performance (Gooty, Gavin, Johnson, Frazier \& Snow, 2009; Keller, 2006; Liao \& Chuang, 2007; Lyons \& Schneider, 2009; Tsai, Chen \& Cheng, 2009) and organizational citizenship behavior (Gooty et al., 2009; Purvanova, Bono \& Dzieweczynksi, 2006) through psychological capital (Gooty, Gavin, Johnson, Frazier \& Snow, 2009). TL is also positively predictive of firm performance (Peterson, Walumbwa, Byron \& Myrowitz, 2009) and team performance (Purvanova \& Bono, 2009).

\section{Positive psychological capital}

Positive psychological capital (hope, resilience, optimism and efficacy) was related to performance in several studies. Some of these studies found better prediction with a composite factor than with the four individual facets (i.e, Luthans, Avolio, Avey \& Norman, 2007). In this sense, several studies indicated that psychological capital as a global construct has positive impacts on employee's performance and OCB (i.e, Luthans, Avolio, Avey \& Norman, 2007; Zhong, 2007; Luthans, Norman, Avolio \& Avey, 2008; Avey, Luthans $\&$ Youssef, 2010). However, as these four positive components are conceptually and psychometrically distinct (i.e, Luthans, Norman, Avolio \& Avey, 2008) sometimes their predictions differ from one to another (i.e: Youssef \& Luthans, 2007; West, Patera \& Carsten, 2009). At team level, optimism predicts better team outcomes (cohesion, cooperation, coordination and performance) in newly formed teams, whereas resilience and efficacy are better predictors when the team is not new and their members have pass through several interactions (West, Patera \& Carsten, 2009).

On the other hand, it was also found that positive emotions generally mediated the relationship between psychological capital and performance (Avey, Wernsing \& Luthans, 2008).

\section{Psychological Flexibility}

There are some studies relating psychological flexibility and performance. For example, in a quasi-experiment quasi-experimental study, Bond, Flaxman, and Bunce (2008) show the moderation effects of psychological flexibility on a control-enhancing work reorganization intervention in a call center. The interven- 
tion enhanced perceptions of job control, and hence its outcomes (such as motivation), for the people who received it, especially for those who had greater psychological flexibility.

In a different research, panel study type, Bond \& Flaxman (2006) also show its positive influence on performance on customer service software, as higher levels of psychological flexibility at time 1 were associated with better job performance at time 3 .

\section{Job satisfaction, well-being and positive emotions}

At the individual level, besides the well constructed review of the job satisfaction-job performance relation by Judge, Thoresen, Bono, and Patton (2001) in which they concluded that job satisfaction was an effective predictor of job performance, other recent research, in line with the happy-productive worker thesis, supports this relationship (i.e: Chiu \& Chen, 2005; Riketta, 2008; Taris \& Schreurs, 2009; Wright, Cropanzano \& Bonett, 2007; Zelenski, Murphy \& Jenkis, 2008). As it was previously pointed out by Judge and collegues' work (2001), this relation was moderated by other variables, one of the most consistent was psychological well-being (Wright, Cropanzano \& Bonett, 2007). Other authors have studied this relation in a more expanded model, finding that job satisfaction mediates the positive relationship between job characteristics (job variety and job significance) and OCB (Chiu \& Chen, 2005).

Although job satisfaction-performance relationship has been studied mainly at individual level, we can find studies at group level too. When considering aggregated job satisfaction, it was found a positive relationship with organization innovation, and job variety as a moderator (Shipton et. al, 2006). In addition, in a recent meta-analysis (Whitman, Van Rooy \& Viswevaran, 2010) the relationship between aggregate job satisfaction and unit-level performance was also found positive significant. Besides unit-level OCB had a moderately strong relationship with unit-level performance. However the notion that OCB is a route through which satisfaction has an impact on performance was scarcely supported (Tsai, Chen \& Liu, 2007).

On the contrary, there is also some divergent evidence on the job satisfaction-performance relationship when controlling certain variables. For example, a recent meta-analysis (Bowling, 2007) showed that this relationship was partially eliminated after controlling variables like core-self evaluations, big five traits or work locus of control; and completely eliminated when controlling organizational based self-esteem. However, in another meta-analysis (Fassina, Jones \& Uggerslev, 2008), studies that considered OCB, instead of performance as the criteria variable, showed an independent effects model where job satisfaction accounted for unique variance in $\mathrm{OCB}$ dimensions, after controlling perceived fairness.

Past empirical evidence has demonstrated that employees' positive mood states predict task performance indirectly through both interpersonal (helping other coworkers and coworker helping and support) and motivational (self-efficacy and task persistence) processes (Tsai, Chen \& Liu, 2007). A series of metaanalyses based on 57 studies indicated that positive affect also predicted task performance. That relationship was stronger for subjectively rated than objectively rated performance (Kaplan, Bradley, Luchman \& Haynes, 2009). In addition, positive emotions were also related to OCB (Kaplan et al., 2009) and deviance behaviors relevant to organizational change (Avey, Wernsing \& Luthans, 2008).

Finally, despite it is not possible throughout crosssectional designs to test the direction of the relationships between employee satisfaction and performance, there is more evidence in line with job satisfaction causing performance than the other way around (Riketta, 2008).

\section{Engagement}

As it has been described before, the definition of engagement, more broadly accepted within academic research context, and which is also used here, focuses on employees' experience of work activity, and not the predictors or outcomes of these experiences. However this does not mean that it is not closely related. Indeed, research evidence shows that engagement predicts performance (Bakker \& Leiter, 2010).

For example, it has been found a positive relationship between engagement and ratings of performance from colleagues and supervisors (Halbesleben \& Wheeler, 2008). In diary studies, employee engagement positively correlated with daily financial returns (Xanthopoulou, Bakker, Demerouti \& Schaufeli, 2009); customers of hotels and restaurants were more loyal and gave higher performance ratings to highly engaged employees (Salanova, Agut \& Peiró, 2005); engaged employee performed more organizational citizenship behaviors (Halbesleben, Harvey \& Bolino, 2009) and better in-role performance (Xanthopoulou, Baker, Heuven, Demerouti \& Schaufeli, 2008).

\section{Flow}

As it has been stated before, little research has been conducted regarding flow experience. However, it is possible to relate some of its components with performance. For instance, Eisenberger, Jones, Stinglhamber, Shanock, and Randall (2005) found that among achievement-oriented employees, high skill and challenge was associated with greater perform- 
ance. In this relation positive mood was found as a mediator.

Other studies, for example, showed that flow predicted in-role and extra-role performance, for only conscientious employees (Demerouti, 2006) and that flow experience has direct and significant influences on service quality (Kuo \& Ho, 2010).

\section{Discussion}

The first matter of concern addressed by the current study has been to investigate whether or not employees' and organizations' growth can be nurtured together. Are mutual gains possible? Or do workers and organizations mainly develop the one at the expense of the other? On the basis of the current review, we find reasonable to formulate that positive organizational practices (e.g., positive climate, positive leadership practices, etc.) and positive psychological outcomes (e.g., workers' satisfaction, work-family balance, etc.) tend to relate positively with desirable organizational outcomes (e.g., performance). In other words, the enhancement of "positivity" in the context work seems to be associated with an increase of organizational gains. In broad terms, the current analyze coheres with the results obtained in a recent review yielded out by van de Voorde, Paauwe, and van Veldhoven (under review). Van de Voorde and collegues' investigation is the only review study that we have found raising the issue of whether organizational interests and employee's health and well-being are compatible or not. In a qualitative and quantitative review (based on 41 studies on Human Resource Management), the authors referred concluded that employees' well being seems to function as mutual gain with performance, mainly when it is considered in terms of happiness and relationships. Thus, at the sight of the coherence showed between the general results of our review and the conclusions depicted in van de Voorde et al. review study, it seems reasonable to state that the evidence collected thus far supports the perspective of mutual gains that is situated in the base of abundance approaches. Mutual gains seem possible, and thus positive psychology's applications to world of organizations might work indeed, as referred by Linley et al. (2010). From our point of view, the abundance approach arises as an interesting alternative to be considered by organizations in detriment of the deficit (problem-solving) strategy traditionally adopted.

We would like to make a clarification up to this point. Some readers might be thinking that the search for mutual gains in the context of work and organizations is not a novelty, which in part is true. In some sense, it is a concern that has been present almost since the establishment of industrial and organizational psychology. Not in vain, positive psychological outcomes such as workers' job satisfaction have been of major concern for researchers. As a matter of fact, the outcome referred might be one of the most widely researched variables of the field, as stated earlier by Spector (1997) and due to the quantity of studies found in the databases nowadays. However, it seems to us that a qualitative change is occurring, an important shift favored by positive psychology movement's influence over the area. Despite the importance traditionally given to employees' well-being, it seems to us that research was ultimately conducted in order to improve organizational gains. As Warren (2010) has referred: "[...] the Human Relation school of management, instigated by Mayo's [...] Hawthorne experiments [...] caught the attention of academics and managers especially, as it highlighted the potential productive benefits of considering employee's emotional wellbeing -for example, individuals' need for sociability, attention from their supervisor, and general desire for recognition, achievement and belonging." But recently, under the frame of abundance approaches, scholars start to conceive well-being at work as an end on its own (i.e., Warren, 2010). In fact, the current review might be considered as an expression of this change of perspective. In opposition with the traditional deficit (problem-solving) perspective, we believe that abundance approaches do honestly commit with employees' growth and health. For that reason, we encourage industrial and organizational psychologists to consider this approach and by doing so to establish a true balance between the both sides implied.

However, we do not intend to state that abundance approaches aren't the subject of betterment or improvement nowadays, or that their applicability and efficacy is yet well established. At this point, we would like to address the second research question that has guided the current study: What does evidence show about the development of theory building, research and application of abundance approaches?

The first issue of relevance is the relative lack of research that has been conducted under the frame of abundance approaches, above all in comparison with the deficit oriented ones which represent the status quo (Linley, Harrington \& Garcea, 2010) along with the history of psychology. At the sight of the reviewed studies, there is some evidence that mutual gains are possible and thus that abundance approaches should be considered as an alternative to the deficit approach. However, it seems to us that it is yet too early to discern the extent to which mutual growth could be nurtured together. Moreover, we believe that we can't yet discriminate whether or not an aspect of organizations' or employees' interests is susceptible to be developed without generating counterparts for the other side. Some outcomes could be in conflict with others. Mutual gains possibility general statement doesn't imply that all levels of workers' health and well-being, on the one hand, and organizational desirable outcomes, on the other, are always compatible or 
will develop in an equal extent. There is some evidence supporting the idea depicted. In opposition to the general obtained results, Van de Voorde et al. (under review) reported that employees' well-being seems to function as a conflicting outcome (and not as a mutual gain) when it is conceived in terms of physical health. Research concerning theses issues is rather scant, as stated above; therefore, any conclusion drawn from it should be cautious for now. Nevertheless, we raise the problem, hoping that future research will provide a better discernment of the variables functioning as a conflicting outcome, together with the extent and circumstances characterizing the phenomena.

Another issue of relevance that has attracted our attention while analyzing the development of abundance approaches is the relative lack of theory building. Many concepts and constructs have been raised under their frame (i.e., servant leadership, engagement, etc.), but it is common to find vague definitions or lack of consensus in relation to them. The concept of Psychological Flexibility might constitute an example of convenient theoretical grounding. The construct referred is framed in an elaborated model of human health, which is grounded in turn in an experimentally well established theory of human language and cognition called Relational Frame Theory (RFT). RFT although being behaviour analytic in a traditional sense, involve implications for a very different behavioural approach to complex human behaviour, beyond the central claim that a particular kind of operant exists. At the time, there are hundreds of works publish on RFT and ACT. At least some empirical work has been done on almost every aspect of the basic theory, with extensions into a wide variety of topics faced by organizational behaviour analysts and several that are part of traditional industrial organizational psychology (Hayes, Bunting, Herbst, Bond \& Barnes-Holmes, 2006).

Along with the generic need for theory building referred, we also find that some degree of methodological development is needed in order to improve the approach oriented towards abundance. The vast majority of the studies reviewed were correlative in nature. Considering the youth of abundance approaches we find that this emphasis on prediction is sufficiently justified. However, we report that a lack of longitudinal studies might be taking place. Along with a lack of diary studies and methodological tools alike that could complement and enrich the data generated through analytic and correlational methods. Moreover, we report that experimental methodology is almost absent in researchers' agenda. Although the absence of experiments and quasi-experiments is partially justified due to early stage of development that currently characterizes abundance approach research program, we believe that this situation should change in the immediate future. Not in vain, we find that the current lack of experimental control affects the internal validity of the results collected thus far. Moreover, we believe this fact to be the cause and the consequence of the lack of theory building referred above. In order to consolidate the abundance approach, we believe that it should be able not just to predict critical events in the context of work and organizations, but also to influence or control them. Up to this point, we would like to report the relative shortage of intervention studies and applied research within the abundance approach. Not in vain, we believe that it might be a consequence, partially at least, of the abovementioned lack of development within the explanatory level of analyze.

In addition, we have found a lack of cross-cultural studies in order to see if determinants of workers' well-being vary across cultures and to what extent. Besides, this is a particularly important point if we consider that more and more international merges are taking place. Moreover, there have been found cross cultural differences in several measures of life satisfaction, including job satisfaction (i.e., Oishi, Diener, Lucas \& Suh, 2009) and differences such as individualistic (vs. collectivistic) cultures, low-power-distance (vs. high-power-distance) cultures, low-uncertaintyavoidance (vs. high-uncertainty-avoidance) cultures, or masculine (vs. feminine) cultures, for example, might vary the results and effects of the positive variables on the different outcomes (i.e., $\mathrm{Ng}$, Sorensen \&Yim, 2009). As an example, as suggested by Avolio et al. (2010), it is possible that in cultures where people follow more equity or egalitarian norms the effects of authentic leadership could be stronger. Moreover, as Fineman (2006) argued we could be making a mistake considering positiveness as universal, in that it probably has cultural roots and subcultural nuances very different.

To close this section, in which we address some issues to be improved for the betterment of abundance approaches, mentioning two subtle risks that might be surrounding abundance approaches themselves, the issue of some of its constructs and "dark side" concepts and the issue of the trap of positivity.

Regarding the first point, some authors have referred a "dark side" within some generally assumed "positive variables". This is the case for engagement and commitment, for example, which depending on their operationalization may be in conflict with employees' well-being (Schaufeli \& Bakker, 2010; Stairs \& Galpin, 2010). That's the reason why we haven't include commitment as a positive individual outcome per se, in that it is usually more related to affective commitment to the organization or as a component of hardy personality (Kobasa, 1979), more than to the experience of being committed as it is the case of engagement. Other researchers have questioned the "positivity" of different leadership practices raised in the frame of positive psychology, such as transformational, authentic, or positive deviant. Regarding this 
issue, it has been argued that such leadership styles target organization financial gains rather than employee's well-being.

Finally, some authors have criticized positive psychology and abundance approaches due to the risk that might be implicit in their accentuation of "the positive". The separation between the negative and the positive is considered as a mistake by Fineman (2006a, 2006b), for example, who argues in favor of negative emotions and other experiences in their capacity to sharpen in intensity and meaning to the positive ones. In this sense, Fineman (2006a, 2006b) claim for the interconnection of positive and negative dynamics. According to Warren (2010), there are several "authors who argue that some degree of negativity is not only necessary for healthy psychological function, but that it is inevitable". Besides, she has considered positive psychology as an expression of "the over-riding requirement $[\ldots]$ to accentuate the positive" that characterizes our socio-historical context. Thus, despite being an attempt "to harness emotional force for the good of organizations and individuals alike", a fact that "can be hardly seen as a negative thing", she has stated that "positive psychology might generate more negativity than it appears" (Warren, 2010). In general terms, we agree with the line of reasoning exposed by those authors. The stress on the positive might lead to the inobservance of the ubiquity and importance of the negative. We do not mean that the stress should be put on the negative. We neither mean that it should be put on both, the positive and the negative at the same time. We believe that abundance approaches should seek individual and organization growth and development, and according to our point of view, positive and negative variables aren't, per se, accurate indicators of them. As we have discussed before, the same variable could be considered as positive or as negative one depending on the context and the person. For that reason, we encourage future research to abandon the traditional focus on positive and negative variables, and work in replacement, with personal and organizational growth-related variables.

Finally, we will consider some of the limitations and strengths of the current study. As a result of the broadness that characterizes the area and considering its huge variety of concepts, the current review only ambitioned to outline a global picture of the field. Specific debates around important particular issues have been avoided on purpose, for instance, whether job satisfaction measurement reflects appropriately or not both, its cognitive and affective nature (Judge, 2001), etc.

On the one hand, it is a qualitative review, not a quantitative one, thus it is subject to interpretation. On the other hand, due to the huge number of concepts and constructs and to our consequent focus in the use of descriptors during the search, it's possible that prominent articles have escaped our notice. However, this seems quite unreasonable, considering that a manual and direct consultancy of the pertinent journals was carried out during the selection processes.

Regarding the strengths of our study; due to the extension of the field, the current review hasn't deepened, as stated above, on each specific issue and debate. However, we believe that an accurate "global picture" of the area has been outlined as a result precisely of the abovementioned approach.

\section{Conclusions and proposal of future research}

The global picture presented outlines a scenario where mutual gains for individuals and organizations seem (more than) possible. Thus we call researchers to consider the alternative of adopting abundance approach instead of the traditional deficit one. In this sense, it's necessary more theoretical development, conceptual definition and model integration. The diversification of methodological procedures is also needed: causal (and longitudinal) designs to deepen our understanding of the causality underlying the correlations that studies have not covered (developing the explanatory level of analysis, diary studies, cross-cultural studies, etc.). And going further, looking for applied research as well.

If future research pays attention to the lacks abovementioned, we believe that positive psychology or abundance approaches in organizations would replace the current status quo of deficit problem solving approaches, obtaining not only good (possible better) organizational gains but social approval and satisfaction over the working environment.

\section{References}

Amiot, C. E., Terry, D. J., Jimmieson, N. L. \& Callan, V. J. (2006). A longitudinal investigation of coping processes during a merger: Implications for job satisfaction and organizational identification. Journal of Management, 32, 552-574.

Andersen, J. A. (2009). When a servant-leader comes knocking. Leadership \& Organization Development Journal, 30, 4-15.

Arnold, K. A., Turner, N., Barling, J., Kelloway, E. K. \& McKee, M. C. (2007). Transformational leadership and psychological well-being: The mediating role of meaningful work. Journal of Occupational Health Psychology, $12,193-203$

Avey, J. B., Hughes, L. W., Norman, S. M. \& Luthans, K. W. (2008). Using positivity, transformational leadership and empowerment to combat employee negativity. Leadership \& Organization Development Journal, 29, 110-126.

Avey, J. B., Luthans, F., Smith, R. M. \& Palmer, N. F. (2010). Impact of positive psychological capital on 
employee well-being over time. Journal of Occupational Health Psychology, 15, 17-28.

Avey, J. B., Wernsing, T. S. \& Luthans, F. (2008). Can positive employees help positive organizational change? Impact of psychological capital and emotions on relevant attitudes and behaviors. Journal of Applied Behavioral Science, 44, 48-70.

Avolio, B. J., Griffith, J., Wernsing, T. S. \& Walumbwa, F. O. (2010). What is authentic leadership development? In P. A. Linley, S. Harrington \& N. Garcea (Eds.), Oxford handbook of positive psychology and work. (pp. 39-51). New York, NY, US: Oxford University Press

Avolio, B. J., Walumbwa, F. O. \& Weber, T. J. (2009). Leadership: Current theories, research, and future directions. Annual Review of Psychology, 60, 421-449.

Ayres, J. \& Malouff, J. M. (2007). Problem-solving training to help workers increase positive affect, job satisfaction, and life satisfaction. European Journal of Work and Organizational Psychology, 16, 279-294.

Bagger, J., Li, A. \& Gutek, B. A. (2008). How much do you value your family and does it matter? The joint effects of family identity salience, family-interference-with-work, and gender. Human Relations, 61, 187-211.

Bakker, A. B. (2008). The work-related flow inventory: Construction and initial validation of the WOLF. Journal of Vocational Behavior, 72, 400-414.

Bakker, A. B. \& Demerouti, E. (2007). The job demandsresources model: State of the art. Journal of Managerial Psychology, 22, 309-328.

Bakker, A. B. \& Demerouti, E. (2008). Towards a model of work engagement. The Career Development International, 13, 209-223.

Bakker, A. B. \& Schaufeli, W. B. (2008). Positive organizational behavior: Engaged employees in flourishing organizations. Journal of Organizational Behavior.Special Issue: Contexts of Positive Organizational Behavior, 29, 147-154.

Bakker, A. B., Schaufeli, W. B., Leiter, M. P. \& Taris, T. W. (2008). Work engagement: An emerging concept in occupational health psychology. Work \& Stress, 22, 187-200.

Bakker, A. B., van Veldhoven, M. \& Xanthopoulou, D. (2010). Beyond the demand-control model: Thriving on high job demands and resources. Journal of Personnel Psychology, 9, 3-16.

Baltes, B. B., Clark, M. A. \& Chakrabarti, M. (2010). Worklife balance: The roles of work-family conflict and workfamily facilitation. In P. A. Linley, S. Harrington \& N. Garcea (Eds.), (pp. 201-212). New York, NY, US: Oxford University Press

Berceli, D. \& Napoli, M. (2006). A proposal for a mindfulness-based trauma prevention program for social work professionals. Complementary Health Practice Review, $11,153-165$.

Berson, Y., Oreg, S. \& Dvir, T. (2008). CEO values, organizational culture and firm outcomes. Journal of Organizational Behavior, 29, 615-633.

Best, R. G., Stapleton, L. M. \& Downey, R. G. (2005). Core self-evaluations and job burnout: The test of alternative models. Journal of Occupational Health Psychology, 10, 441-451.

Bond, F. W. (2004). Getting the balance right: The need for a comprehensive approach to occupational health. Work \& Stress, 18, 146-148.

Bond, F. W. \& Flaxman, P. E. (2006). The ability of psychological flexibility and job control to predict learning, job performance, and mental health. Journal of Organizational Behavior Management, 26, 113-130.

Bond, F. W., Flaxman, P. E. \& Bunce, D. (2008). The influence of psychological flexibility on work redesign: Mediated moderation of a work reorganization intervention. Journal of Applied Psychology, 93, 645-654.

Bond, F.W., Flaxman, P.E., van Veldhoven, M.J.P.M \& Biron, M. (2010). The impact of Psychological Flexibility and Acceptance and Commitment Therapy (ACT) on Health and Productivity at Work. In Houdmont, J. \& Leka, S. (Eds.), Contemporary Occupational Health Psychology. Global perspectives on research and practice Volume 1. (pp. 296-313). Chichester,West Sussex, UK: Wiley-Blackwell

Bond, F. W., Hayes, S. C. \& Barnes-Holmes, D. (2006). Psychological flexibility, ACT, and organizational behavior. Journal of Organizational Behavior Management, 26, 25-54.

Bono, J. E., Foldes, H. J., Vinson, G. \& Muros, J. P. (2007). Workplace emotions: The role of supervision and leadership. Journal of Applied Psychology, 92, 1357-1367.

Bono, J. E. \& Judge, T. A. (2003). Core self-evaluations: A review of the trait and its role in job satisfaction and job performance. European Journal of Personality.Special Issue: Personality and Industrial, Work and Organizational Applications, 17, S5-S18.

Bowler, W. M. \& Brass, D. J. (2006). Relational correlates of interpersonal citizenship behavior: A social network perspective. Journal of Applied Psychology, 91, 70-82.

Bowling, N. A. (2007). Is the job satisfaction-job performance relationship spurious? A meta-analytic examination. Journal of Vocational Behavior, 71, 167-185.

Boyar, S. L. \& Mosley, D. C., Jr. (2007). The relationship between core self-evaluations and work and family satisfaction: The mediating role of work-family conflict and facilitation. Journal of Vocational Behavior, 71, 265-281.

Brotheridge, C. M. \& Lee, R. T. (2005). Impact of workfamily interference on general well-being: A replication and extension. International Journal of Stress Management, 12, 203-221.

Butts, M. M., Vandenberg, R. J., DeJoy, D. M., Schaffer, B. S. \& Wilson, M. G. (2009). Individual reactions to high involvement work processes: Investigating the role of empowerment and perceived organizational support. Journal of Occupational Health Psychology, 14, 122136.

Cameron, K. S., Dutton, J. E. \& Quinn, R. E. (2003). Positive organizational scholarship: Foundations of a new discipline. San Francisco: Berrett-Koehler.

Carr, J. C., Boyar, S. L. \& Gregory, B. T. (2008). The moderating effect of work-family centrality on work-family 
conflict, organizational attitudes, and turnover behavior. Journal of Management, 34, 244-262.

Chiu, S. \& Chen, H. (2005). Relationship between job characteristics and organizational citizenship behavior: The mediational role of job satisfaction. Social Behavior and Personality, 33, 523-540.

Csikszentmihalyi, M. (1997). Finding flow: The psychology of engagement with everyday life. New York: Harper Collins.

Csikszentmihalyi, M. (1999). If we are so rich, why aren't we happy? American Psychologist, 54, 821-827.

Cunningham, C. J. L. \& De La Rosa, G. M. (2008). The interactive effects of proactive personality and work-family interference on well-being. Journal of Occupational Health Psychology, 13, 271-282.

De Cuyper, N. \& De Witte, H. (2006). Autonomy and workload among temporary workers: Their effects on job satisfaction, organizational commitment, life satisfaction, and self-rated performance. International Journal of Stress Management, 13, 441-459.

De Cuyper, N. \& De Witte, H. (2006). The impact of job insecurity and contract type on attitudes, well-being and behavioural reports: A psychological contract perspective. Journal of Occupational and Organizational Psychology, 79, 395-409.

De Cuyper, N. \& De Witte, H. (2007). Job insecurity in temporary versus permanent workers: Associations with attitudes, well-being, and behaviour. Work \& Stress, 21, 6584.

De Cuyper, N., Notelaers, G. \& De Witte, H. (2009). Job insecurity and employability in fixed-term contractors, agency workers, and permanent workers: Associations with job satisfaction and affective organizational commitment. Journal of Occupational Health Psychology, 14, 193-205.

de Lange, A. H., De Witte, H. \& Notelaers, G. (2008). Should I stay or should I go? examining longitudinal relations among job resources and work engagement for stayers versus movers. Work \& Stress, 22, 201-223.

Demerouti, E. (2006). Job characteristics, flow, and performance: The moderating role of conscientiousness. Journal of Occupational Health Psychology, 11, 266-280.

Egan, T. M. \& Song, Z. (2008). Are facilitated mentoring programs beneficial? A randomized experimental field study. Journal of Vocational Behavior, 72, 351-362.

Eisenberger, R., Jones, J. R., Stinglhamber, F., Shanock, L. \& Randall, A. T. (2005). Flow experiences at work: For high need achievers alone? Journal of Organizational Behavior, 26, 755-775.

European Agency for Safety and Health at Work: Milczarek, M., Schneider, E., Rial Gonzalez, E. (2009). OSH in figures: stress at work-facts and figures. Luxembourg: European Communities.

Fassina, N. E., Jones, D. A. \& Uggerslev, K. L. (2008). Meta-analytic tests of relationships between organizational justice and citizenship behavior: Testing agent-system and shared-variance models. Journal of Organizational Behavior, 29, 805-828.
Fineman, S. (2006a). On being positive: Concerns and counterpoints. Academy of Management Review, 31, 270-291.

Fineman, S. (2006b). Reply: Accentuating the positive? Academy of Management Review, 31, 306-308.

Ford, M. T., Heinen, B. A. \& Langkamer, K. L. (2007). Work and family satisfaction and conflict: A meta-analysis of cross-domain relations. Journal of Applied Psychology, 92, 57-80.

Garrosa, E., Moreno-Jiménez, B., Rodríguez-Muñoz, A. \& Rodríguez-Carvajal, R. (in press). Role stress and personal resources in nursing: A cross-sectional study of burnout and engagement. International Journal of Nursing Studies.

Giri, V. N. \& Kumar, B. P. (2007). Impact of organizational climate on job satisfaction and job performance. Psychological Studies, 52, 131-133.

Glas $\varnothing$, L. \& Einarsen, S. (2008). Emotion regulation in leader-follower relationships. European Journal of Work and Organizational Psychology, 17, 482-500.

Gong, Y., Huang, J. \& Farh, J. (2009). Employee learning orientation, transformational leadership, and employee creativity: The mediating role of employee creative selfefficacy. Academy of Management Journal, 52, 765-778.

Gooty, J., Gavin, M. \& Ashkanasy, N. M. (2009). Emotions research in OB: The challenges that lie ahead. Journal of Organizational Behavior, 30, 833-838.

Gooty, J., Gavin, M., Johnson, P. D., Frazier, M. L. \& Snow, D. B. (2009). In the eyes of the beholder: Transformational leadership, positive psychological capital, and performance. Journal of Leadership \& Organizational Studies, 15, 353-367.

Grandey, A. A., Cordeiro, B. L. \& Crouter, A. C. (2005). A longitudinal and multi-source test of the work-family conflict and job satisfaction relationship. Journal of Occupational and Organizational Psychology, 78, 305323.

Greenleaf, R. K. (1977). Servant leadership. New York: Paulist Press.

Gumusluoglu, L. \& Ilsev, A. (2009). Transformational leadership, creativity, and organizational innovation. Journal of Business Research, 62, 461-473.

Hakanen, J. J., Schaufeli, W. B. \& Ahola, K. (2008). The job demands-resources model: A three-year cross-lagged study of burnout, depression, commitment, and work engagement. Work \& Stress, 22, 224-241.

Halbesleben, J. R. B., Harvey, J. \& Bolino, M. C. (2009). Too engaged? A conservation of resources view of the relationship between work engagement and work interference with family. Journal of Applied Psychology, 94, 1452-1465.

Halbesleben, J. R. B. \& Wheeler, A. R. (2008). The relative roles of engagement and embeddedness in predicting job performance and intention to leave. Work \& Stress, 22, 242-256.

Hamilton, F. (2005). Practicing servant-leadership: Succeeding through trust, bravery, and forgiveness. Academy of Management Review, 30, 875-877.

Hayes, S. C., Bunting, K., Herbst, S., Bond, F. W. \& Barnes- 
Holmes, D. (2006). Expanding the scope of organizational behavior management: Relational frame theory and the experimental analysis of complex human behavior. Journal of Organizational Behavior Management, 26, 123

Hayes, S.C., Luoma, J.B., Bond, F.W., Masuda, A. \& Lillis, J. (2006). Acceptance and commitment therapy: Model, processes and outcomes. Behavior Research and Therapy, 44, 1-25.

Hayes, S. C., Strosahl, K. D. \& Wilson, K. G. (1999). Acceptance and commitment therapy: An experiential approach to behavior change. New York, NY, US: Guilford Press.

Higgins, E. T. (1997). Beyond pleasure and pain. American Psychologist, 52, 1280-1300.

Hill, E. J. (2005). Work-family facilitation and conflict, working fathers and mothers, work-family stressors and support. Journal of Family Issues, 26, 793-819.

Ilies, R., Wilson, K. S. \& Wagner, D. T. (2009). The spillover of daily job satisfaction onto employees' family lives: The facilitating role of work-family integration. Academy of Management Journal, 52, 87-102.

Jain, A. K. \& Sinha, A. K. (2005). General health in organizations: Relative relevance of emotional intelligence, trust, and organizational support. International Journal of Stress Management, 12, 257-273.

Jensen, S. M. \& Luthans, F. (2006). Entrepreneurs as authentic leaders: Impact on employees' attitudes. Leadership \& Organization Development Journal, 27, 646-666.

Johnson, H. M. \& Spector, P. E. (2007). Service with a smile: Do emotional intelligence, gender, and autonomy moderate the emotional labor process? Journal of Occupational Health Psychology, 12, 319-333.

Joseph, E. E. \& Winston, B. E. (2005). A correlation of servant leadership, leader trust, and organizational trust. Leadership \& Organization Development Journal, 26, 622.

Judge, T. A., Erez, A., Bono, J. E. \& Thoresen, C. J. (2002). Are measures of self-esteem, neuroticism, locus of control, and generalized self-efficacy indicators of a common core construct? Journal of Personality and Social Psychology, 83, 693-710.

Judge, T. A., Heller, D. \& Klinger, R. (2008). The dispositional sources of job satisfaction: A comparative test. Applied Psychology: An International Review, 57, 361372.

Judge, T. A., Locke, E. A. \& Durham, C. C. (1997). The dispositional causes of job satisfaction: A core evaluations approach. Research in Organizational Behavior, 19, 151-188.

Judge, T. A., Thoresen, C. J., Bono, J. E. \& Patton, G. K. (2001). The job satisfaction-job performance relationship: A qualitative and quantitative review. Psychological Bulletin, 127, 376-407.

Jung, D., Wu, A. \& Chow, C. W. (2008). Towards understanding the direct and indirect effects of CEOs' transformational leadership on firm innovation. The Leadership Quarterly, 19, 582-594.
Kafetsios, K. \& Zampetakis, L. A. (2008). Emotional intelligence and job satisfaction: Testing the mediatory role of positive and negative affect at work. Personality and Individual Differences, 44, 712-722.

Kaplan, S., Bradley, J. C., Luchman, J. N. \& Haynes, D. (2009). On the role of positive and negative affectivity in job performance: A meta-analytic investigation. Journal of Applied Psychology, 94, 162-176.

Keller, R. T. (2006). Transformational leadership, initiating structure, and substitutes for leadership: A longitudinal study of research and development project team performance. Journal of Applied Psychology, 91, 202-210.

Kobasa, S. C. (1979). Stressful life events, personality, and health: An inquiry into hardiness. Journal of Personality and Social Psychology, 37, 1-11.

Kuo, T. \& Ho, L. (2010). Individual difference and job performance: The relationships among personal factors, job characteristics, flow experience, and service quality. Social Behavior and Personality, 38, 531-552.

Lapierre, L. M. \& Allen, T. D. (2006). Work-supportive family, family-supportive supervision, use of organizational benefits, and problem-focused coping: Implications for work-family conflict and employee well-being. Journal of Occupational Health Psychology, 11, 169-181.

Lapierre, L. M., Spector, P. E., Allen, T. D., Poelmans, S., Cooper, C. L., O'Driscoll, M. P. et al . (2008). Family-supportive organization perceptions, multiple dimensions of work - family conflict, and employee satisfaction: A test of model across five samples. Journal of Vocational Behavior, 73, 92-106.

Larson, M. \& Luthans, F. (2006). Potential added value of psychological capital in predicting work attitudes. Journal of Leadership \& Organizational Studies, 13, 7592.

Liao, H. \& Chuang, A. (2007). Transforming service employees and climate: A multilevel, multisource examination of transformational leadership in building longterm service relationships. Journal of Applied Psychology, 92, 1006-1019.

Liao, H. \& Rupp, D. E. (2005). The impact of justice climate and justice orientation on work outcomes: A cross-level multifoci framework. Journal of Applied Psychology, 90, 242-256.

Liden, R. C., Wayne, S. J., Zhao, H. \& Henderson, D. (2008). Servant leadership: Development of a multidimensional measure and multi-level assessment. The Leadership Quarterly, 19, 161-177.

Linley, P. A. \& Joseph, S. (2004). Applied positive psychology: A new perspective for professional practice. In P. A. Linley \& S. Joseph (Eds.), (pp. 3-12). Hoboken, NJ, US: John Wiley \& Sons Inc.

Linley, P. A., Harrington, S. \& Garcea, N. (2010). Finding the positive in the world of work. In P. A. Linley, S. Harrington \& N. Garcea (Eds.), Oxford handbook of positive psychology and work. (pp. 3-9). New York, NY, US: Oxford University Press.

Liu, J., Siu, O. \& Shi, K. (2010). Transformational leadership and employee well-being: The mediating role of trust 
in the leader and self-efficacy. Applied Psychology: An International Review, 59, 454-479.

Lord, R. G., Diefendorff, J. M., Schmidt, A. M. \& Hall, R. J. (2010). Self-regulation at work. Annual Review of Psychology, 61, 543-568.

Luna-Arocas, R. \& Camps, J. (2008). A model of high performance work practices and turnover intentions. Personnel Review, 37, 26-46.

Luthans, F. (2002). Positive organizational behavior: Developing and managing psychological strengths. Academyof Management Executive, 16, 57-72.

Luthans, F. \& Avolio, B. J. (2009a). The "point" of positive organizational behavior. Journal of Organizational Behavior, 30, 291-307.

Luthans, F. \& Avolio, B. J. (2009b). Inquiry unplugged: Building on hackman's potential perils of POB. Journal of Organizational Behavior, 30, 323-328.

Luthans, F., Avolio, B. J., Avey, J. B. \& Norman, S. M. (2007). Positive psychological capital: Measurement and relationship with performance and satisfaction. Personnel Psychology, 60, 541-572.

Luthans, F., Norman, S. M., Avolio, B. J. \& Avey, J. B. (2008). The mediating role of psychological capital in the supportive organizational climate-employee performance relationship. Journal of Organizational Behavior.Special Issue: Contexts of Positive Organizational Behavior, 29, 219-238.

Luthans, F. \& Youssef, C. M. (2007). Emerging positive organizational behavior. Journal of Management, 33, 321-349.

Lyons, J. B. \& Schneider, T. R. (2009). The effects of leadership style on stress outcomes. The Leadership Quarterly, 20, 737-748.

Mardanov, I. T., Heischmidt, K. \& Henson, A. (2008). Leader-member exchange and job satisfaction bond and predicted employee turnover. Journal of Leadership \& Organizational Studies, 15, 159-175.

Marks, M. L. (2006). Workplace recovery after mergers, acquisitions, and downsizings: Facilitating individual adaptation to major organizational transitions. Organizational Dynamics, 35, 384-399.

Mauno, S., Kinnunen, U. \& Ruokolainen, M. (2006). Exploring work and organization-based resources as moderators between work-family conflict, well-being, and job attitudes. Work \& Stress, 20, 210-233.

Mayer, D. M., Bardes, M. \& Piccolo, R. F. (2008). Do servant-leaders help satisfy follower needs? an organizational justice perspective. European Journal of Work and Organizational Psychology, 17, 180-197.

Mesmer-Magnus, J. R. \& Viswesvaran, C. (2005). Convergence between measures of work-to-family and familyto-work conflict: A meta-analytic examination. Journal of Vocational Behavior, 67, 215-232.

Meyerson, S. L. \& Kline, T. J. B. (2008). Psychological and environmental empowerment: Antecedents and consequences. Leadership \& Organization Development Journal, 29, 444-460.

Moreno-Jiménez, B., Mayo, M., Sanz-Vergel, A. I., Geurts,
S., Rodríguez-Muñoz, A. \& Garrosa, E. (2009). Effects of Work-Family conflict on employees' well-being: The moderating role of recovery strategies. Journal of Occupational Health Psychology, 14, 427-440.

Muse, L., Harris, S. G., Giles, W. F. \& Feild, H. S. (2008). Work-life benefits and positive organizational behavior: Is there a connection? Journal of Organizational Behavior.Special Issue: Contexts of Positive Organizational Behavior, 29, 171-192.

Neubert, M. J., Kacmar, K. M., Carlson, D. S., Chonko, L. B. \& Roberts, J. A. (2008). Regulatory focus as a mediator of the influence of initiating structure and servant leadership on employee behavior. Journal of Applied Psychology, 93, 1220-1233.

Ng, T. W. H., Sorensen, K. L. \& Yim, F. H. K. (2009). Does the job satisfaction - job performance relationship vary across cultures? Journal of Cross-Cultural Psychology, 40, 761-796.

Nielsen, K. \& Cleal, B. (2010). Predicting flow at work: Investigating the activities and job characteristics that predict flow states at work. Journal of Occupational Health Psychology, 15, 180-190.

Nielsen, K. \& Munir, F. (2009). How do transformational leaders influence followers' affective well-being? exploring the mediating role of self-efficacy. Work \& Stress, 23, 313-329.

Nielsen, K., Randall, R., Yarker, J. \& Brenner, S. (2008). The effects of transformational leadership on followers' perceived work characteristics and psychological wellbeing: A longitudinal study. Work \& Stress, 22, 16-32.

Oishi, S., Diener, E., Lucas, R. E. \& Suh, E. M. (2009). In Diener E. (Ed.), Cross-cultural variations in predictors of life satisfaction: Perspectives from needs and values Springer Netherlands.

Oreg, S. (2006). Personality, context, and resistance to organizational change. European Journal of Work and Organizational Psychology, 15, 73-101.

Ozcelik, H., Langton, N. \& Aldrich, H. (2008). Doing well and doing good: The relationship between leadership practices that facilitate a positive emotional climate and organizational performance. Journal of Managerial Psychology.Special Issue: The Emotions of Managing, 23, 186-203.

Panaccio, A. \& Vandenberghe, C. (2009). Perceived organizational support, organizational commitment and psychological well-being: A longitudinal study. Journal of Vocational Behavior, 75, 224-236.

Peterson, S. J., Walumbwa, F. O., Byron, K. \& Myrowitz, J. (2009). CEO positive psychological traits, transformational leadership, and firm performance in high-technology start-up and established firms. Journal of Management, 35, 348-368.

Petrides, K. V. \& Furnham, A. (2006). The role of trait emotional intelligence in a gender-specific model of organizational variables. Journal of Applied Social Psychology, 36, 552-569.

Piccolo, R. F., Judge, T. A., Takahashi, K., Watanabe, N. \& Locke, E. A. (2005). Core self-evaluations in Japan: 
Relative effects on job satisfaction, life satisfaction, and happiness. Journal of Organizational Behavior, 26, 965 984.

Podsakoff, N. P., LePine, J. A. \& LePine, M. A. (2007). Differential challenge stressor-hindrance stressor relationships with job attitudes, turnover intentions, turnover, and withdrawal behavior: A meta-analysis. Journal of Applied Psychology, 92, 438-454.

Pomaki, G., Karoly, P. \& Maes, S. (2009). Linking goal progress to subjective well-being at work: The moderating role of goal-related self-efficacy and attainability. Journal of Occupational Health Psychology, 14, 206-218.

Proudfoot, J. G., Corr, P. J., Guest, D. E. \& Dunn, G. (2009). Cognitive-behavioural training to change attributional style improves employee well-being, job satisfaction, productivity, and turnover. Personality and Individual Differences, 46, 147-153.

Purvanova, R. K. \& Bono, J. E. (2009). Transformational leadership in context: Face-to-face and virtual teams. The Leadership Quarterly, 20, 343-357.

Purvanova, R. K., Bono, J. E. \& Dzieweczynski, J. (2006). Transformational leadership, job characteristics, and organizational citizenship performance. Human Performance, 19, 1-22.

Ramlall, S. J. (2008). Enhancing employee performance through positive organizational behavior. Journal of Applied Social Psychology, 38, 1580-1600.

Rego, A. \& Pina e Cunha, M. (2009). Do the opportunities for learning and personal development lead to happiness? it depends on work-family conciliation. Journal of Occupational Health Psychology, 14, 334-348.

Riketta, M. (2008). The causal relation between job attitudes and performance: A meta-analysis of panel studies. Journal of Applied Psychology, 93, 472-481.

Ruiz, C.O., Rios, F. L. \& Martin, S.G. (2008). Psychological intervention for profesional burnout in the Palliative Care Unit at Gregorio Marañon University Hospital. Medicina Preventiva, 15, 93-97.

Rodríguez-Carvajal, R. (2007). Emotion regulation and social interaction process in resident physician burnout. Ediciones Universidad Autónoma, Madrid.

Rodríguez-Sánchez, A. M., Schaufeli, W. B., Salanova, M. $\&$ Cifre, E. (2008). Flow experience among information and communication technology users. Psychological Reports, 102, 29-39.

Salanova, M., Agut, S. \& Peiró, J. M. (2005). Linking organizational resources and work engagement to employee performance and customer loyalty: The mediation of service climate. Journal of Applied Psychology. Special Section: Theoretical Models and Conceptual AnalysesSecond Installment, 90, 1217-1227.

Salanova, M., Bakker, A. B. \& Llorens, S. (2006). Flow at work: Evidence for an upward spiral of personal and organizational resources. Journal of Happiness Studies, 7, 1-22.

Sanz-Vergel, A. I., Demerouti, E., Moreno-Jiménez, B. \& Mayo, M. (2010). Work-family balance and energy: A day-level study on recovery conditions. Journal of Vocational Behavior, 76, 118-130.
Schaufeli, W. B. \& Bakker, A. B. (2010). Defining and measuring work engagement: Bringing clarity to the concept. In A. B. Bakker \& M. P. Leiter (Eds.), (pp. 10-24). New York, NY, US: Psychology Press.

Schaufeli, W. B., Bakker, A. B. \& Van Rhenen, W. (2009). How changes in job demands and resources predict burnout, work engagement and sickness absenteeism. Journal of Organizational Behavior, 30, 893-917.

Schaufeli, W. B. \& Salanova, M. (2007). Efficacy or inefficacy, that's the question: Burnout and work engagement, and their relationships with efficacy beliefs. Anxiety, Stress \& Coping: An International Journal, 20, 177-196.

Schulte, M., Ostroff, C. \& Kinicki, A. J. (2006). Organizational climate systems and psychological climate perceptions: A cross-level study of climate-satisfaction relations. Journal of Occupational and Organizational Psychology, 79, 654-671.

Seery, B. L. \& Corrigall, E. A. (2009). Emotional labor: Links to work attitudes and emotional exhaustion. Journal of Managerial Psychology, 24, 797-813.

Seligman, M. E. P. \& Csikszentmihalyi, M. (2000). Positive psychology: An introduction. American Psychologist, 55, 5-14. doi:10.1037/0003-066X.55.1.5

Shipton, H. J., West, M. A., Parkes, C. L., Dawson, J. F. \& Patterson, M. G. (2006). When promoting positive feelings pays: Aggregate job satisfaction, work design features, and innovation in manufacturing organizations. European Journal of Work and Organizational Psycho$\log y, 15,404-430$.

Sonnentag, S. \& Zijlstra, F. R. H. (2006). Job characteristics and off-job activities as predictors of need for recovery, well-being, and fatigue. Journal of Applied Psychology, 91, 330-350.

Spector, P. E. (1997). Job satisfaction: Application, assessment, causes, and consequences. Thousand Oaks, CA, US: Sage Publications, Inc.

Stairs, M. \& Galpin, M. (2010). Positive engagement: From employee engagement to workplace happiness. In P. A. Linley, S. Harrington \& N. Garcea (Eds.), Oxford handbook of positive psychology and work. (pp. 155-172). New York, NY, US: Oxford University Press.

Sy, T., Tram, S. \& O'Hara, L. A. (2006). Relation of employee and manager emotional intelligence to job satisfaction and performance. Journal of Vocational Behavior, 68, 461-473.

Taris, T. W. \& Schreurs, P. J. G. (2009). Well-being and organizational performance: An organizational-level test of the happy-productive worker hypothesis. Work \& Stress, 23, 120-136.

Thompson, C. A. \& Prottas, D. J. (2006). Relationships among organizational family support, job autonomy, perceived control, and employee well-being. Journal of Occupational Health Psychology, 11, 100-118.

Trougakos, J. P., Beal, D. J., Green, S. G. \& Weiss, H. M. (2008). Making the break count: An episodic examination of recovery activities, emotional experiences, and positive affective displays. Academy of Management Journal, $51,131-146$. 
Tsai, W., Chen, C. \& Liu, H. (2007). Test of a model linking employee positive moods and task performance. Journal of Applied Psychology, 92, 1570-1583.

Tsai, W., Chen, H. \& Cheng, J. (2009). Employee positive moods as a mediator linking transformational leadership and employee work outcomes. The International Journal of Human Resource Management, 20, 206-219.

Ulrich, D., (2010). Foreword: The Abundant Organization. In P. A. Linley, S. Harrington \& N. Garcea (Eds.), Oxford handbook of positive psychology and work. (pp. XVIIXXI). New York, NY, US: Oxford University Press.

Van de Voorde, K., Paauwe, J. \& van Veldhoven, M. (under review). HRM, well-being and organizational performance: a systematic review of the literature.

Van Dierendonck, D. \& Nuijten, I. (in press). The Servant Leadership Survey: Development and Validation of a Multidimensional Measure. Journal of Business and Psychology.

Van Dijk, P. A. \& Brown, A. K. (2006). Emotional labour and negative job outcomes: An evaluation of the mediating role of emotional dissonance. Journal of Management \& Organization.Special Issue: Managing Emotions and Con-flict in the Workplace, 12, 101-115.

Walumbwa, F. O., Lawler, J. J., Avolio, B. J., Wang, P. \& Shi, K. (2005). Transformational leadership and work-related attitudes: The moderating effects of collective and selfefficacy across cultures. Journal of Leadership \& Organizational Studies, 11, 2-16.

Warren, S. (2010). What's wrong with being positive? In P. A. Linley, S. Harrington \& N. Garcea (Eds.), Oxford handbook of positive psychology and work. (pp. 313322). New York, NY, US: Oxford University Press.

Washington, R. R., Sutton, C. D. \& Feild, H. S. (2006). Individual differences in servant leadership: The roles of values and personality. Leadership \& Organization Development Journal, 27, 700-716.

Welbourne, J. L., Eggerth, D., Hartley, T. A., Andrew, M. E. \& Sanchez, F. (2007). Coping strategies in the workplace: Relationships with attributional style and job satisfaction. Journal of Vocational Behavior, 70, 312-325.

West, B. J., Patera, J. L. \& Carsten, M. K. (2009). Team level positivity: Investigating positive psychological capacities and team level outcomes. Journal of Organizational Behavior, 30, 249-267.

Whitman, D. S., Van Rooy, D. L. \& Viswesvaran, C. (2010). Satisfaction, citizenship behaviors, and performance in work units: A meta-analysis of collective construct relations. Personnel Psychology, 63, 41-81.

Wiese, B. S. \& Freund, A. M. (2005). Goal progress makes one happy, or does it? longitudinal findings from the work domain. Journal of Occupational and Organizational Psychology, 78, 287-304.

Wooten, L. P. \& Cameron, K. S. (2010). Enablers of a posi- tive strategy: Positively deviant leadership. In P. A. Linley, S. Harrington \& N. Garcea (Eds.), Oxford handbook of positive psychology and work. (pp. 53-65). New York, NY, US: Oxford University Press.

World Health Organization Constitution (1946) Official Records of the World Health Organization, 2, 100.

Wright, T. A., Cropanzano, R. \& Bonett, D. G. (2007). The moderating role of employee positive well being on the relation between job satisfaction and job performance. Journal of Occupational Health Psychology, 12, 93-104.

Wright, T. A. \& Quick, J. C. (2009a). The emerging positive agenda in organizations: Greater than a trickle, but not yet a deluge. Journal of Organizational Behavior, 30, 147-159.

Wright, T. A. \& Quick, J. C. (2009b). The role of positivebased research in building the science of organizational behavior. Journal of Organizational Behavior, 30, 329336.

Xanthopoulou, D., Baker, A. B., Heuven, E., Demerouti, E. \& Schaufeli, W. B. (2008). Working in the sky: A diary study on work engagement among flight attendants. Journal of Occupational Health Psychology, 13, 345-356.

Xenikou, A. \& Simosi, M. (2006). Organizational culture and transformational leadership as predictors of business unit performance. Journal of Managerial Psychology, 21, 566-579.

Yanchus, N. J., Eby, L. T., Lance, C. E. \& Drollinger, S. (2010). The impact of emotional labor on work-family outcomes. Journal of Vocational Behavior, 76, 105-117.

Youssef, C. M. \& Luthans, F. (2007). Positive organizational behavior in the workplace: The impact of hope, optimism, and resilience. Journal of Management, 33, 774-800.

Youssef, C. M. \& Luthans, F. (2010). An integrated model of psychological capital in the workplace. In P. A. Linley, S. Harrington \& N. Garcea (Eds.), Oxford handbook of positive psychology and work. (pp. 277-288). New York, NY, US: Oxford University Press.

Zapf, D. \& Holz, M. (2006). On the positive and negative effects of emotion work in organizations. European Journal of Work and Organizational Psychology, 15, 128.

Zelenski, J. M., Murphy, S. A. \& Jenkins, D. A. (2008). The happy-productive worker thesis revisited. Journal of Happiness Studies, 9, 521-537.

Zhong, L. (2007). Effects of psychological capital on employees' job performance, organizational commitment, and organizational citizenship behavior. Acta Psychologica Sinica, 39, 328-334.

Zickar, M. J., Balzer, W. K., Aziz, S. \& Wryobeck, J. M. (2008). The moderating role of social support between role stressors and job attitudes among roman catholic priests. Journal of Applied Social Psychology, 38, 29032923.
Manuscript received: 17/10/2010

Review received: $15 / 11 / 2010$

Accepted: 15/11/2010 